\title{
THE RELEVANCE OF THE INDIVIDUALISM - COLLECTIVISM (IC) FACTOR FOR THE MANAGEMENT OF DIVERSITY IN THE SOUTH AFRICAN NATIONAL DEFENCE FORCE
}

\author{
G A J VAN DYK \\ F S DE KOCK \\ Department of Industrial Psychology \\ Faculty of Military Science \\ Stellenbosch University
}

\begin{abstract}
The aim of this study was to determine the level of adherence of cultural groups to their stereotypical group orientations, i.e. White and Coloured officers tend to be more individualistic, whereas Black officers portray more collectivistic characteristics. Secondly, to determine if their cultural behavior and practices relate to their level of individual or collectivistic orientation. The Individualism-Collectivism Interpersonal Assessment Inventory (ICIAI) of Matsumoto (1992) and a self-constructed questionnaire to measure cultural practices, were administered to 88 undergraduate officer students of the South African Military Academy. The results indicated that no significant differences existed in the Individualism-Collectivism factor between the three groups studied. Only five of the twenty cultural activities (stereotypically associated with Individualism and Collectivism) correlated significantly with the IndividualismCollectivism factor. These findings, the implications thereof and suggestions for possible further research are discussed.
\end{abstract}

\section{OPSOMMING}

Die doel van hierdie studie was om die vlak van betrokkenheid van kultuurgroepe tov hul stereotipiese groepsorientasies te bepaal, met ander woorde Blanke en Kleurling offisiere is meer individualisties, waar Swart offisiere meer kollektiwisties in hul kulturele aktiwiteite is. Tweedens, om te bepaal of hulle kulturele gedrag in verband staan met hul individualistiese of kollektiwistiese oriëntasie. Die "Individualism-Collectivism Interpersonal Assessment Inventory" (ICIAI) van Matsomoto (1992) en 'n tweede vraelys, opgestel deur die skrywers om kulturele aktiwiteite te meet, is afgeneem tov 88 voorgraadse offissierstudente van die Suid Afrikaanse Militêre Akademie. Die resultate het aangedui dat daar geen statisties beduidende verskille bestaan tov die individualistiese en kollektiwistiese faktor van die drie kultuurgroepe nie. Net vyf van die twintig kulturele aktiwiteite, getoets deur die tweede vraelys, het 'n beduidende korrelasie met die individualistiese en kollektiwistiese telling getoon. Die resultate, die implikasies daarvan, asook voorstelle vir moontlike verdere navorsing word bespreek.

Most people would agree that South African culture has experienced significant changes in its various environments during the past decade, for instance society, politics, the military, and even higher education. Walton (1994) wrote whenever a group of people spend a period of time together, a culture is formed. Culture is a pattern of values and beliefs reflected in outer behaviors. Culture is shaped by these lasting values that you're given at an early age. Smit and Cronje (2001) explained that culture can be manifested in many ways: dress, language, food, gestures, manners and in various other forms, yet the bulk of cultural components such as beliefs, norms, values, standards, perceptions, attitudes, and priorities are less visible, and hence much harder to deal with successfully. Matsumoto (1996, p.16) defined culture as "the set of attitudes, values, beliefs and behaviours shared by a group of people, but different for each individual, communicated from one generation to the next". From this definition he claims that culture is not rooted in biology, race or nationality. According to him, culture is dynamic and, therefore, changes with the times.

Change in the military environment required the previous South African Defence Force (SADF), and various other military forces, to integrate into a new South African National Defence Force (SANDF). In this regard, Van Dyk and Heinecken (1997) stated that the new SANDF came into being at midnight, just after the first democratic elections in South Africa. It now consists of the SADF with a full-time force strength of 85000 members, the homeland armies of Transkei, Bophutatswana, Venda and Ciskei with a combined force strength of 10000 , as well as the African National Congress' Umkhonto we Sizwe (MK) with a force strength of 20000 , and the Pan African Congress' Azanian People's Liberation Army (APLA), with 6000 members.

It can be assumed that the culture of the various forces differed radically from one another. For instance, the largest percentage

Requests for copies should be addressed: GAJ van Dyk, Department of Industrial Psychology, Faculty of Military Academy, University of Stellenbosch, Private Bag X2, Saldanha, 7395 of SADF members were White Afrikaans and English speaking males and females with more Eurocentric, Western, and individualistic values. The rest of the forces possibly enjoyed a way of life with a more Afrocentric value system, presumably of a collectivistic nature. Table 1 reflects the opposing characteristics of the two different cultures as described by Sue and Sue (1999, p.175) and Van der Walt (1997, p.31).

TABLE 1

ChaRACTERISTICS OF INDIVIDUALISTIC AND COMMUNALISTIC CULTURES

\begin{tabular}{|c|c|}
\hline $\begin{array}{l}\text { Individualism } \\
\text { (First the individual, then the } \\
\text { community. We are, because I am.) }\end{array}$ & $\begin{array}{l}\text { Communalism } \\
\text { (First the community, then } \\
\text { the individual. I am because we are.) }\end{array}$ \\
\hline $\begin{array}{l}\text { 1. A high regard for the individual } \\
\text { elevates it above the group. }\end{array}$ & $\begin{array}{l}\text { 1. A high regard for the group } \\
\text { elevates it above the individual. }\end{array}$ \\
\hline 2. Individual independence. & 2. Dependence on people. \\
\hline $\begin{array}{l}\text { 3. The opinion of the group is } \\
\text { not so important. }\end{array}$ & 3. Strong group pressure. \\
\hline $\begin{array}{l}\text { 4. Individual initiative is highly } \\
\text { regarded - personal achievement } \\
\text { is more important than attention } \\
\text { to the community. }\end{array}$ & $\begin{array}{l}\text { 4. Individual initiative is not } \\
\text { appreciated - good human relations } \\
\text { are a priority. }\end{array}$ \\
\hline 5. Competition. & 5. Co-operation. \\
\hline $\begin{array}{l}\text { 6. The rights of the individual } \\
\text { are stressed. }\end{array}$ & $\begin{array}{l}\text { 6. Duties towards the community } \\
\text { are emphasised. }\end{array}$ \\
\hline $\begin{array}{l}\text { 7. Values such as formality, } \\
\text { independence, self-sufficiency, } \\
\text { are highly regarded. }\end{array}$ & $\begin{array}{l}\text { 7. Values such as friendliness, } \\
\text { helpfulness, hospitality, patience } \\
\text { and brotherhood are highly } \\
\text { regarded. }\end{array}$ \\
\hline
\end{tabular}

(Sue \& Sue, 1999, p.175; Van der Walt, 1997, p.31) 
Triandis (1993) described these different opposing characteristics of a culture as a cultural syndrome and characterised it as "a set of elements of a subjective culture organised around a theme". Eaton and Louw (2000) used Hofstede's definitions of individualism and collectivism to explain the two themes or cultural syndromes. Individualism (I) is defined as a tendency within a culture to focus on the individual rather than on the group, and collectivism/ communalism (C) as a tendency within a culture to forward gregariousness and group orientation. This dimension, individualism-collectivism, distinguishes between cultures that value individual effort as opposed to collective team effort (Kruger \& Roodt, 2003). The IC-factor refers to the degree to which a culture encourages, fosters and facilitates the needs, wishes, desires and values of an autonomous and unique self against those of a group. Members of individualistic cultures see themselves as separate and autonomous individuals, whereas members of collectivistic cultures see themselves as fundamentally connected with one another. In individualistic cultures, personal needs and goals take precedence over the needs of others, whereas, in a collectivistic culture, individuals' needs are sacrificed to satisfy the group (Matsumoto, 2000). Hwang, Francesco and Kessler (2003) stated that for individualists, social behaviour is determined by attitudes, personal rights and contracts, whereas for collectivists such behaviours are rooted in norms, obligations, and duties; individualists view relationships as rational exchanges, whereas collectivists emphasize the communality of the relationship. This means that people from different cultures view the world, their environment, their workplace and, by implication, their military colleagues through their own cultural filters. Matsumoto (2000) defined this natural tendency as ethnocentrism.

The more people/soldiers show an inflexible ethnocentrism (an inability to go beyond one's own cultural filters in interpreting the behaviour of others), the more one can expect diversityrelated conflict and power struggles, especially in an organisation such as the SANDF with its highly diverse workforce.

It is important to note that the Military Academy students that participated in this study were from culturally diverse backgrounds. When comparing the diversity of first-year students of 1997 with those of 2002, it is evident that cultural representativity between the two groups improved radically (see Table 2).

In 1997, $78 \%$ of the first years came from a traditionally Western cultural background with possibly a more individualistic orientation, whilst only $14 \%$ came from a traditionally African cultural background and value system with possibly a more collectivistic orientation. In comparison, the first year group of 2002 comprised of $28 \%$ of students from a more Westernised culture with $54 \%$ coming from a more African orientated value system. Although Triandis (cited in Eaton \& Louw, 2000) is of opinion that African cultures are considered collectivistic, he also wrote that "most cultures include a mixture of individualistic and collectivistic elements". Soh and Leong (2002, p.3) also said "it has been noted that within individualistic or collectivistic cultures, differences exit".
Mpofu (1994; 1999) is of opinion that the British education system, Western dominated, global and free-market economy as well as the "town life that was better than rural life" changed the collectivistic culture of the Shona group in Zimbabwe to a more individualistic way of life. Within the South African context Rieger \& Blignaut (1996) are of the opinion that the level of nutrition, empowerment and training could have an effect on individualism and collectivism. Eaton \& Louw (2000, p.4) support this in their research, "we dealt with university students, who typically are more exposed to individualism than are members of the general population". For the purpose of this study, similar factors like school education, urbanisation, military training, tertiary education and so forth are supposed to have a transformational influence on the group of officers from a more collectivistic to a more individualistic cultural orientation. On the other side military training and living with officers from other ethnic groups may also have a transformational effect on officers from a more individualistic approach to change to a more collectivistic way of life.

A series of tragic incidents (with the possibility of underlying racial conflict) happened in the SANDF. The question was asked whether it is important to note that the study focused on determining how strongly Western orientated White and African orientated Black officers still feel about the traditional individualistic and collectivistic values and cultural behaviour and practices. The origin of the third group, the so-called Coloureds, can be traced back to various ethnic groups viz. the Whites, Europeans, Khoi-Khoi, Indians, Chinese and Malays. Despite the mixture of influences, this group portrays a predominant Western, Afrikaans/English and pro-White culture, and they feel culturally closer to Whites than Blacks (Corder, 2001; Leukes, 2003; Mullett, 2002; Vosloo, 1998). More individualistic cultural values could thus be expected from them.

Generally, managing of cultural diversity refers to creating an environment in which the employee (in this case soldiers) can perform optimally, irrespective of nationality, sex, culture and values (Rieger \& Blignaut, 1996). If soldiers acquire respect and appreciation for ethnic differences (such as reflected in the ICfactor) within the SANDF, the organisation would eventually only benefit from it, especially with regards to competition, cooperation, time and family orientation, mobility and loyalty. The management of cultural diversity should contribute to a large extent to work satisfaction, productivity and preparedness of forces in the SANDF.

The researchers are of the opinion that the more flexible (i.e. similar) the IC-factor of officers from different racial groups are, the easier it must be to manage cultural diversity in the SANDF. The potential for diversity related conflict is then expected to be less.

\section{Statement of problem}

From the above-mentioned theoretical discussion, the following research aims for this study are stipulated. Firstly, to determine the level of adherence of Black, White and Coloured officers to stereotypical positions, i.e. do White and Coloured officers tend to portray strong individualistic characteristics

TABLE 2

DEMOGRAPHIC COMPARISON OF MILITARY ACADEMY STUDENTS OF 1997 AND 2002

\begin{tabular}{|c|c|c|c|c|c|c|c|c|c|c|c|c|c|}
\hline \multirow[t]{2}{*}{ YEAR } & \multirow[t]{2}{*}{$\mathbf{N}$} & \multicolumn{4}{|c|}{ GENDER } & \multicolumn{6}{|c|}{ CULTURE } & \multirow[b]{2}{*}{ Indian } & \multirow[b]{2}{*}{$\%$} \\
\hline & & Male & $\%$ & Female & $\%$ & Black & $\%$ & White & $\%$ & Coloured & $\%$ & & \\
\hline 1997 & 124 & 87 & 70 & 37 & 30 & 17 & 14 & 94 & 78 & 5 & 4 & 2 & 2 \\
\hline 2002 & 92 & 69 & 75 & 23 & 25 & 50 & 54 & 26 & 28 & 14 & 16 & 2 & 2 \\
\hline
\end{tabular}


and Black officers portray strong collectivistic characteristics? Stated otherwise, the aim is to determine if there is a relationship between ethnicity and culture, as measured by the IC-factor, amongst junior officers of this sample in the SANDF. Secondly, to determine if the officers' cultural behaviour and practices are in accordance with their individual or collective orientation.

\section{Hypotheses}

Hypothesis 1

There are no significant differences in the levels of individualism and collectivism of the three cultural groups studied.

\section{Hypothesis 2}

There is no significant relationship between levels of individualism and collectivism and the corresponding cultural behavior traditionally assumed to accompany them.

\section{Hypothesis 3}

The reliability and factorial validity of the ICIAI of Matsumoto (1996) in this sample is acceptable.

\section{METHOD}

\section{Participants}

The sample consisted of 88 participants that yielded a representative sample of the population of undergraduate officer-students of the South African Military Academy. Of the participants, $78 \%$ were male and $22 \%$ were female. The racial composition of the sample was $40 \%$ Black, $46 \%$ White, $12 \%$ Coloured and 2,5\% Indian. Due to practical considerations, the small Indian group was not included in any of the analyses. The mean age of the sample was 24 years ( $S D=3,2$ years), where the average tenure was 4,4 years ( $\mathrm{SD}=2,5$ years) in the SANDF. In the sample $35 \%$ of the students were first years, $20 \%$ secondyears, and $44 \%$ third-years. The SANDF was represented as follows: 10\% Air Force, 27\% Navy, 50\% Army, 4\% Military Intelligence and $8 \%$ Military Health Services. Most officerstudents were in the rank group of Lieutenant (64\%). The sample compares favourably with that of the population of junior officers of the Military Academy with respect to rank, age, gender and race composition. A more detailed breakdown of the sample in terms of ethnicity and year-group is provided in Table 3.

TABLE 3

SAMPLE COMPSITION: BREAKDOWN OF RACE ACROSS YEAR-GROUPS

\begin{tabular}{lcccccc}
\hline YEAR & \multicolumn{5}{c}{ RACE } \\
\hline & & Black & White & Coloured & Indian & $\begin{array}{c}\text { No } \\
\text { Response }\end{array}$ \\
\hline First year & $32,2 \%$ & $16,7 \%$ & $10,7 \%$ & $3,6 \%$ & $1,2 \%$ & 0 \\
Second year & $17,8 \%$ & $8,3 \%$ & $7,1 \%$ & $2,4 \%$ & $0 \%$ & 0 \\
Third year & $40,5 \%$ & $10,7 \%$ & $23,8 \%$ & $4,8 \%$ & $1,2 \%$ & 0 \\
No response & 9,5 & 1,2 & 0 & 0 & 0 & 8,3 \\
& $100 \%$ & $36,9 \%$ & $41,7 \%$ & $10,7 \%$ & $2,4 \%$ & 8,3 \\
\hline
\end{tabular}

\section{Measuring Instruments}

Students completed two questionnaires relating to culture, the first of which was the Individualism-Collectivism Interpersonal Assessment Inventory (ICIAI) of Matsumoto (1996). This questionnaire provides a measure of "contextspecific IC tendencies in interpersonal situations" (Matsumoto, 2000, p.46; Matsumoto, Weissman, Preston, Brown \& Kupperbusch, 1997). It is a 76-item inventory that requires students to indicate their agreement $(0=$ strongly disagree,
$6=$ strongly agree) with statements pertaining to individualisticcollectivistic type values. From the four different contexts originally measured by the questionnaire, namely friends, close friends, colleagues and strangers, the students were to respond to, a single combined index of IC which was created (Matsumoto, 2000). The reasoning behind this being that averaging IC across different themes would provide a better estimate of IC tendencies in general.

The second questionnaire was constructed by the authors to measure cultural practices and behaviours traditionally associated with individualism and collectivism. The items were developed to reflect commonly held beliefs about ICbehaviours found in literature (e.g. Sue \& Sue, 1999; Van der Walt, 1997). It consisted of 20 statements students had to respond to on a Likert-type scale ranging for example from 1 (time is money) to 7 (time is more spent on relationships), relating to their usual behaviours in cultural terms. The following is an example of an item to evaluate a theme as seen in the results in Table 6:

\begin{tabular}{llll}
\hline Theme & Description & Scale & Description \\
\hline $\begin{array}{l}\text { Time and time } \\
\text { consciousness }\end{array}$ & $\begin{array}{l}\text { (time is money } \\
\text { for individualistic }\end{array}$ & 1234567 & $\begin{array}{l}\text { Time more spent } \\
\text { culture) }\end{array}$ \\
& & & $\begin{array}{l}\text { on enjoyment of } \\
\text { relationship for a } \\
\text { more collectivistic } \\
\text { culture }\end{array}$ \\
\hline
\end{tabular}

\section{Procedure}

Accompanied by a covering letter from the researchers, the questionnaires were completed during a voluntary meeting scheduled in conjunction with the student representative council. The set of questionnaires was introduced to them as an evaluation of their cultural behaviour and practices Respondents were encouraged to express their cultures freely when responding to items. Furthermore, respondents were assured of the confidentiality of their responses.

\section{Statistical Analyses}

The data were analysed with the SPSS Statistical Package (Kinnear \& Gray, 2000). The significance of differences in levels of individualism and collectivism between the three cultural groups was determined by a one-way analysis of variance (ANOVA). Pearson-product moment correlations ( $r$ ) were used to determine the association between levels of IC and cultural practices traditionally associated with the construct (Kerlinger, 1986). A significance value of $p=0,05$ was used for all tests.

Principal factor analysis of the 19 items of the ICIA composite IC index was performed, using Varimax rotation and the Scree test of Cattell to determine the amount of factors to extract. Following Kaiser's (1958) criterion (number of eigen values greater than unity), the analysis yielded five factors that accounted for $66,58 \%$ of the variance. The factors that were extracted were uninterpretable, and had items loading simultaneously on both individualism and collectivism in most cases. This is not in line with the results of Mpofu (1994), where only two clear factors were obtained, namely individualism and collectivism. It suggests that these factors do not emerge as clearly in this South African sample. The internal consistency (Cronbach's alpha) of the composite index of the ICIA for this sample was 0,84 . This is higher than the alphas found in previous studies, e.g. the average standardised alpha of 0,70 reported by Matsumoto (1992). The self-constructed Cultural Behaviours Questionnaire had a Cronbach alpha reliability of 0,80 .

Although the ICIA's factorial validity differed from other studies, both measuring instruments showed acceptable psychometric properties as observed in the relatively high internal consistency. 


\section{RESULTS}

The descriptive statistics of the levels of IC for the respective cultural groups are reported in Table 4 .

TABLE 4

DESCRIPTIVE STATISTICS: MEANS, STANDARD DEVIATIONS AND LEVELS OF IC CULTURAL GROUPS

\begin{tabular}{lccc}
\hline RACE & MEAN & SD & N \\
\hline Black & 3,63 & 0,56 & 31 \\
Coloured & 3,74 & 0,86 & 9 \\
White & 3,39 & 0,61 & 35 \\
Total & 3,53 & 0,62 & 75 \\
\hline
\end{tabular}

Note that low levels of IC indicate cultural behavior that leans more towards individualism, and vice versa.

An inspection of the means for the respective groups reveals that Coloured participants in this sample exhibited the highest levels of collectivism $(8=3,74)$, followed by the Black $(8=3,63)$ and White $(8=3,39)$ participants. Furthermore, the Black group had the lowest variance $(\mathrm{SD}=0,55)$.

The significance of differences in levels of IC between the three cultural groups was tested by means of a one-way analysis of variance. The results are reported in Table 5 .

\section{TABle 5}

ONE-WAY ANALYSIS OF VARIANCE: SIGNIFICANCE OF DIFFERENCE IN MEAN IC-SCORES BETWEEN CULTURAL GROUPS

\begin{tabular}{lccccc}
\hline & $\begin{array}{c}\text { Sum of } \\
\text { Squares }\end{array}$ & df & $\begin{array}{c}\text { Mean } \\
\text { Square }\end{array}$ & F & p(F) \\
\hline Between Groups & 1,402 & 2 & 0,701 & 1,827 & 0,168 \\
Within Groups & 27,620 & 72 & 0,384 & & \\
Total & 29,022 & 74 & & & \\
\hline
\end{tabular}

As is evident, no statistically significant differences were found in levels of IC between cultural groups in this sample $(\mathrm{F}(2,72)=1,827, \mathrm{p}>, 05)$. The main effect of culture on IC was calculated, resulting in an omega squared with a value of 0,021 . Thus, cultural group affiliation, as measured by race in this sample, explained only $2,1 \%$ of the variance in levels of IC. Therefore, the hypothesis that no significant differences exist between the levels of IC among the three cultural groups was supported.

To determine the relationship between IC and cultural practices traditionally associated with individualism and collectivism, Pearson-product moment correlations (r) were calculated. The correlations between levels of IC and different cultural practices are reported in Table 6 . Note that the right pole of each item refers to high collectivism scores on that item, as proposed by Van der Walt (1997). Therefore, a positive correlation can be interpreted to indicate a confirmation of the hypothesis that the levels of IC measured manifests in the associated traditional IC-behavior.

Only five of the twenty cultural behaviours traditionally associated with IC correlated significantly with levels of IC in the sample. The strongest associations were found with rewards basis $(\mathrm{r}=0,40 ; \mathrm{p}=0,001)$, followed by view of authority and social order $(r=0,31 ; p=0,007)$, preference for working in groups $(r=0,25$; $\mathrm{p}=0,031)$, decision making by groups $(\mathrm{r}=0,25 ; \mathrm{p}=0,027)$, and eating seen as a social experience $(\mathrm{r}=0,25 ; \mathrm{p}=(0,031)$. Therefore, subjects that were more collectivistic were more likely to prefer rewards to be conferred on group performance, they preferred group-decision making above individual decision-making, as well as working in groups. Furthermore, they preferred respecting authority and social order rather than challenging it, and they saw eating as a social experience rather than as a necessity. No other statistically significant relationships were found. Thus, the second hypothesis was supported in only a minority of the statements (5 out of 20).

TABLE 6

\section{Pearson Product moment Correlations: THE Relationshit} BETWEEN IC AND CULTURAL BEHAVIOURS

\begin{tabular}{lc}
\hline THEME & $\boldsymbol{r}$ \\
\hline Greeting: informal vs formal & 0,04 \\
Greeting: own way vs culture's way & 0,19 \\
Communication: direct and explicit vs indirect and implicit & 0,06 \\
Speaking out in public: no reservations vs hesitant & $-0,03$ \\
Eating: necessity vs social experience & $0,25^{*}$ \\
Eating: prefer alone vs prefer with others & 0,10 \\
Time: value promptness vs value relationships & 0,00 \\
Relationships: nuclear family vs extended family & 0,08 \\
After marriage focus on: spouse and children vs own parents, & 0,02 \\
brothers and sisters & $-0,01$ \\
Women are equal to men vs they must submit to men & 0,21 \\
Value orientation: individual and independent vs group and & \\
conformity & 0,31 ** \\
Authority and social order: challenge it vs respect it & $-0,01$ \\
Work emphasis: job vs relationships & $0,25 *$ \\
Work preference: alone vs in a group & $0,25 *$ \\
Decision-making: by individuals vs groups & $-0,01$ \\
Leadership: leader serves group vs group serves leader & $-0,05$ \\
Expressing emotions: easy vs keep them to self & 0,09 \\
Perceptions of conflict: embrace it vs avoid it & $-0,02$ \\
Locus of control: internal vs external & 0,40 ** \\
Rewards basis: on individual performance vs on group performance & \\
* Correlation is significant at the 0,05 level (2-tailed). & \\
& \\
**relation is significant at the 0,01 level (2-tailed). & \\
\hline
\end{tabular}

The last hypothesis to be tested concerned the transportability of the ICIA of Matsumoto (1992) to the South African context. As reported in the preceding section, the ICIA showed acceptable psychometric properties in the sense that it yielded a relatively high measure of internal consistency, although the same factors could not be observed as in previous studies.

\section{DISCUSSION}

The results indicate no statistically significant differences in the levels of IC of the different cultural groups (Table 4). The absence of significant differences in IC, as one aspect of culture, can be due to various factors. Mpofu $(1994 ; 1999)$ and Eaton and Louw (2000) discussed various factors, as previously mentioned, to which students in Zimbabwe and respectively in South Africa were exposed. These probably contributed to a shift from a collectivistic to a more individualistic tendency in these studies. Leong (2001) also wrote when cultures come into contact, it is inevitable that some cultural change will occur among the groups in contact. Leong called the people, as a result of the process, the integrationists. These individuals are trying to adopt and integrate the best of both cultures. Similarly, it is assumed that these factors have had similar results in the present sample under study.

In the same line of reasoning it is noted that forty four percent of the original test sample (see Table 3 ) consisted of third year 
students. This increases the possibility of exposure to factors similar to those in the Zimbabwe and South Africa's students' experience, such as secondary education, tertiary education, a global and free-market economy and military training and courses.

Singelis and Triandis (1995) are of the opinion that people who function within an upper class in a modern, industrial-urban and fast-changing environment tend to become more individualistic. Due to the fast changing transformation process in the SANDF, during the last five years, students in the current study have been exposed to rapid changes with regard to military culture and representivity in the context of diversity in the SANDF.

The results indicate that students no longer adhere to extreme forms of individualism or collectivism, but that there may be a shift towards a moderation that no longer reflects adherence to the traditional stereotypical orientations. This is a strong indicator of a flexible ethnocentrism amongst the officerstudents of the Military Academy, which could be expected to make the existing cultural group more compatible and support the effective management of cultural diversity within the future SANDF.

This is a constructive state of affairs in the perceptions of the officers at the Military Academy since they were born from a past laced with division and conflict. As a case in point, in the American Army Dovidio, Gaertner, Kawakami and Hodson (2002) reported the opposite. In that study it was reported that white-black power struggles are rife and that only thirty nine percent of blacks (compared with sixty eight percent of whites) reported their race relations and circumstances as a good experience.

The results in Table 6 support the above-mentioned view by indicating that only five out of the twenty items still reflect traditional orientations in terms of the IC-factor. From this it can be derived that the students also flexibly associate with behavioural patterns or customs, which specifically associates with the IC-factor. Reid (2002, p. 103) supports this more flexible approach in peoples' cultural customs and writes, " there are significant overlaps among social class groups and also among ethnic groups in their lifestyles, family practices, and social interactions."

The five items (Table 6) at hand may also have value within a military culture. Participants that were more collectivistic were more likely to prefer rewards to be conferred on group performance, they preferred group-decision making above individual-decision making, as well as working in groups. Furthermore, they preferred respecting authority and social order rather than challenging it, and they saw eating as a social experience rather than as a necessity.

The first four items or factors support the military culture of group work and group cohesion, the respect for higher authority and the rank structure. The need to eat, which is viewed as a social experience, may very well be incorporated in the military tradition of formal dinners.

In general, this study has indicated that the future leaders of the SANDF tend to be more similar than they are different, in cultural terms at least. Moreover, this process could continue in this line, if the notion of acculturation (Matsumoto, 2000) is accepted. Furthermore, the value of this research is that it indicates that education and more specifically tertiary education can play an imperative role in shaping and preparing officers to effectively manage aspects such as cultural diversity within the SANDF.

The limitations of this study include the fact that the research design did not provide for observing changes in levels of IC between years of study. This is a common weakness of a crosssectional study (Kerlinger, 1986). Indeed, this is a topic for further research in a longitudinal-type study that investigates acculturation as a phenomenon. Furthermore, Eaton and Louw (2000) warn in their study that the results of research conducted with university students should not be compared with the broader population since students might possibly be exposed to more individualistic practices. Thus, the results of this study can not be generalised to the broader officer population of the SANDF.

The inclusion of other dimensions of culture that relate to organisational processes, such as that of power distance (Hofstede, 1980) would greatly contribute to the impact of the current findings. The investigation of gender differences in the experience of the IC-factor should also form part of any future research project. Lastly, it is recommended that future cultural studies in the South African context should make use of homegrown measures of cultural variability, as the replication of the factorial validity found in foreign studies proved to be problematic.

\section{REFERENCES}

Corder, C.K. (2001). The identification of a multi-ethnic South African typology. Ongepubliseerde proefskrif, Universiteit van Pretoria, Pretoria.

Dovidio, J.F., Gaertner, S.L., Kawakami, K. \& Hodson, G. (2002). Why Can't Just Get Along? Interpersonal Biases and Interracial Distrust. Cultural Diversity and Ethnic Minority Psychology, 8 (2), 88-102.

Eaton, L. \& Louw, L. (2000). Culture and Self in South Africa: Individualism/Collectivism Predictions. Journal of Social Psychology, 140 (2), p 210-218.

Hwang, A., Francesco, A.M. \& Kessler, E. (2003). The Relationship Between Indiviualism-Collectivism, Face, and Feedback and Learning Processes in Hong Kong, Singapore, and the United States. Journal of Cross-Cultural Psychology, 34 (1), 72-91.

Hofstede, G. (1980). Culture's consequences: International differences in work-related values. Newbury Park: Sage.

Kaiser, H.F. (1985). "The Varimax Criterion for Analytic Rotation in Factor Analysis", Psychometrika, 23, 187-200.

Kerlinger, F.N. (1986). Foundations of behavioral research (3rd Ed.) Orlando: Harcourt Brace.

Kinnear, P.R. \& Gray, C.D. (2000). SPSS for Windows made simple: release Hove: Psychology Press.

Kruger, T. \& Roodt, G. (2003). Hofstede in VSM - 94 Revisited: Is it Reliable and Valid? Journal of Industrial Psychology, 29 (1), 75-82.

Leong, F.T.L. (2001). The Role of Acculturation in the Career Adjustment of Asian American Workers: A Test of Leong and Chou's (1994) Formulations. Cultural Diversity and Ethnic Minority Psychology, 7 (3), 262-273.

Leukes, G.S. (2003). Die ervaringe van Swart Afrikaanssprekende ouers wat Engels met hul kinders praat. Ongepubliseerde Mskripsie, Universteit van Wes-Kaapland, Bellville.

Matsumoto, D., Weissman, M., Preston, K., Brown, B. \& Kupperbusch, C. (1997). The Individualism-Collectivism Interpersonal Assessment Inventory. Journal of Cross-Cultural Psychology, 28 (6), 743-767.

Matsumoto, D. (1992). The Individualism-Collectivism Interpersonal Assessment Inventory: A Domain Specific Measure of Individualism and Collectivism. Culture and Emotion Research Laboratory, Department of Psychology. San Francisco: State University.

Matsumoto, D. (1996). Culture and Psychology. Stanford, CT: Thomson Learning.

Matsumoto, D. (2000). Culture and Psychology. Stanford, CT: Thomson Learning.

Mpofu, E. (1994). Exploring the self-concept in an African culture. Journal of Genetic Psychology, 155 (3), 341-354.

Mpofu, E. (1999). Modernity and subjective well-being in Zimbabween college students. South African Journal of Psychology 29 (4), 191-201. 
Mullett, C. (2002). 'n Kruiskulturele ondersoek na die verband tussen individualisme/kollektiwisme en eensaamheid by adolessente. Ongepubliseerde M-verhandeling, Universiteit van die Vrystaat, Bloemfontein.

Rieger, H.S. \& Blignaut, C.J.H. (1996). Individualiteit, kollektiwiteit en fokus van beheer as mikroveranderlikes van diversiteit. Journal of Industrial Psychology, 22 (3), 35-42.

Reid, P.T. (2002). Multicultural Psychology: Bringing Together Gender and Ethnicity. Cultural Diversity and Ethnic Minority Psychology, 8 (2), 103-114.

Singelis, T.M. \& Triandis, H.C. (1995). Horizontal and Vertical Dimensions of Individualism and Collectivism: A Theoretical and Measurement Refinement. Cross-Cultural Research, 29 (3), 240-276.

Smit, P.J. \& Cronjé, G.J. De J. (2001). Management Principles: A Contemporary Edition for Africa. Landsdowne: Juta.

Soh, S. \& Leong, F.T.L. (2002). Validity of Vertical and Horizontal Individualism and Collectivism in Singapore: Relationships
With Values and Interests. Journal of Cross-Cultural Psychology, 33(1), 3-15.

Sue, D.W. \& Sue, D. (1999). Counselling the Culturally Different: Theory and Practice. New York: Wiley.

Triandis, H.C. (1993). Collectivism and Individualism as Cultural syndromes. Cross-Cultural Research, 27 (3-4), 155-181.

Van der Walt, B.J. (1997). Afrocentric or Eurocentric. Potchefstroom: Potchefstroomse Universiteit.

Van Dyk, G.A.J. \& Heinecken, L. (1997). Coping with integration A Socio-psychological Toolkit for Armed Forces in Southern Africa. Paper presented at the Congress of the South African Political Science Association, Mmabatho, 8-10 October.

Vosloo, M. (1998). Die verband tussen etniese identiteit, etniese bewustheid en selfbeeld vir verskillende etniese groepe. Ongepubliseerde M-skripsie, Universiteit van Stellenbosch, Stellenbosch.

Walton, S.J. (1994). Cultural Diversity In The Workplace. New York: Minor Press. 